\title{
Die staat van toegevoegde waarde as komponent van finansiële verslaggewing in die RSA
}

\author{
A.P. du Plessis \\ Departement Bedryfsekonomie, Universiteit Vista, Privaatsak X613, Port Elizabeth 6000, Republiek van Suid-Afrika \\ D.S. Joubert* \\ Departement Rekeningkunde, UOVS, Posbus 339, Bloemfontein 9300, Republiek van Suid-Afrika
}

Ontvang 26 November 1990; aanvaar 7 Maart 1991

\begin{abstract}
The value added statement as component of financial reporting in the RSA The value added statement was developed due to a need for more understandable financial information for the uninformed user of financial statements. Although not required by the Companies Act, since 1977 numerous South African companies have included a value added statement in their financial reports. The question can, however, be asked whether the inclusion of a statement of value added in financial reports will not put financial information at the disposal of a larger group of existing and potential users of financial statements. In such a case the inclusion of the statement should be made compulsory and the contents be standardized. During a study of the reasons for the publication and the presentation of the information of this statement by South African companies, it was found that companies probably publish this statement for the annual competitions for financial statements. The information contents of the statement is therefore disregarded.
\end{abstract}

\begin{abstract}
Verskeie Suid-Afrikaanse maatskappye sluit sedert 1977 'n staat van toegevoegde waarde in hul jaarverslae in sonder dat die staat in die Maatskappywet vereis word. Hierdie staat het ontwikkel as gevolg van 'n behoefte aan meer verstaanbare finansiële inligting aan oningeligte gebruikers van finansiële verslae. Die vraag kan egter gevra word of die insluiting daarvan in finansiële verslae nie die finansiële inligting vir 'n groter groep gebruikers verstaanbaar maak en daarom verplig moet word nie. Hierdie ondersoek het die rede vir publikasie van die staat by Suid-Afrikaanse maatskappye en die aanbiedingsmetode van die staat in finansiële verslaggewing nagevors. Die resultate van die ondersoek dui egter daarop dat maatskappye die staat in alle waarskynlikheid met die oog op die jaarlikse kompetisies vir finansiële jaarverslae insluit en dus die inligtingswaarde daarvan misken.
\end{abstract}

*Aan wie alle navrae en korrespondensie gerig moet word.

\section{Inleiding}

Die Westerse Wêreld beleef sedert die 1970's ' $n$ toename in sosiale bewuswording. Hierdie situasie lei tot 'n groter bewustheid vir die bewaring en aanwending van beide natuurlike en menslike hulpbronne. Suid-Afrika en sy ekonomie funksioneer nie in isolasie van die res van die wêreld nie en daarom vind ontwikkelings in die wêreld ook hul aanklank in Suid-Afrika. Dit is daarom nie verbasend dat sosiale bewustheidsaksies ook in Suid-Afrika bespeur word nie.

In mikroverband word die bestuur van ondernemings geensins uitgesluit van die effek van hierdie ontwikkelings nie. Alhoewel baie van die bewustheidsaksies nie wetlik afgedwing word nie, is dit tog vir die verantwoordelike bestuurder van belang om van die ontwikkelings in sosiale bewuswording kennis te neem. Bestuur is daarvoor verantwoordelik om na die belange van al die belangegroepe van 'n onderneming om te sien. Indien dit tot die voordeel van enige van die belangegroepe van die onderneming is dat daar op sekere ontwikkelings in die bedryfsmilieu van die onderneming gereageer moet word, behoort die bestuurslui as verteenwoordigers van die belangegroepe van die onderneming enige toepaslike aksie te inisieer.

Alhoewel die sosiale bewustheidsaksies gewoonlik met die ondememing se optrede in die gemeenskap geassosieer word, strek dié verantwoordelikheid ook wyer. Dit sluit ook verslaggewing van die aktiwiteite van die onderneming aan belanghebbendes in. In Suid-Afrikaanse verband is daar geen wetlike verpligting op ondernemings om oor sosiale aksies verslag te doen nie. Die verslae wat in die jaarverslae van maatskappye vereis word, is volgens Werth (1985: 1) toegespits op die behoeftes van aandeelhouers en krediteure van maatskappye. Die Maatskappywet vereis in Afdeling 286(3) byvoorbeeld bloot dat finansiële verslaggewing volgens algemeen aanvaarde rekeningkundige praktyk moet geskied. Die Maatskappywet vereis verder dat die verslae 'n redelike weergawe van die maatskappy se stand van sake en resultate van bedrywighede moet wees. Volgens Skedule 4 van die Wet behoort die jaarverslag van 'n maatskappy minstens uit 'n balansstaat, 'n inkomstestaat, 'n direkteursverslag en ' $n$ ouditeursverslag te bestaan.

'n Tendens wat seden 1975 reeds in verskeie Westerse lande voorkom, is die insluiting van 'n staat van toegevoegde waarde in finansiële verslae. Die rede vir hierdie ontwikkeling kan in alle waarskynlikheid in die bespreking van hierdie staat in 'The Corporate Report' van 1975 gevind word. Hierdie verslag wat deur 'The Accounting Standards Steering Committee' in die Verenigde Koninkryk saamgestel is, het aanbeveel dat 'n staat van toegevoegde waarde, onder andere, by finansiële jaarverslae ingesluit word ('The Corporate Report', 1975: 49). Hierdie ontwikkeling het reeds sedert 1977 aanklank in die jaarverslae van Suid-Afrikaanse maatskappye gevind (Du Plessis, 1987: 243).

Die staat van toegevoegde waarde word nog nie deur die Suid-Afrikaanse Maatskappywet vereis nie. Alhoewel baie maatskappye die voorstel van 'The Corporate Report' (1975) met betrekking tot die samestelling van die staat volg, bestaan daar nog geen standaard vir die uitleg van die staat of vir die samestelling van die items van die staat nie. 
Verskeie maatskappye in Suid-Afrika publiseer egter reeds state van toegevoegde waarde in hul finansičle jaarverslae. Die Buro vir Finansiële Analise aan die Universiteit van Pretoria en die Instituut vir Geoktrooieerde Rekenmeesters ken ook tydens die beoordeling van die finansièle jaarverslae van maatskappye vir doeleindes van jaarlikse toekennings vir verslaggewing deur maatskappye, verskeie punte toe vir die insluiting van die staat van toegevoegde waarde in finansiêle verslae (persoonlike mededeling deur die Buro aan die outeurs). As gevolg hiervan geniet die insluiting van 'n staat van toegevoegde waarde in die jaarverslae van maatskappye reeds baie prominensie, terwyl daar steeds 'n gebrek aan riglyne vir die samestelling van die staat bestaan.

Aangesien dit voorkom asof die staat van toegevoegde waarde in die afsienbare toekoms steeds in finansie̋le verslae van maatskappye ingesluit sal word, blyk dit daarom van belang te wees om vas te stel watter waarde aan die staat van toegevoegde waarde geheg moet word. Verder is dit ook belangrik om vas te stel watter nut die staat vir gebruikers van finansiële verslae het ten einde te bepaal of die staat enigsins in die finansiéle jaarverslae van SuidAfrikaanse maatskappye ingesluit moet word. Alvorens antwoorde op hierdie aspekte aangespreek word, is dit nodig dat 'n bepaalde perspektief aan die staat van toegevoegde waarde verleen word deur onder meer aandag te skenk aan die volgende aspekte: Sosiale verslaggewing; eksterne finansiële verslaggewing; die konsep toegevoegde waarde asook die samestelling van die staat van toegevoegde waarde.

\section{Soslale verslaggewing}

Sosiale verantwoordelikheid dui op 'n groter mate van verantwoordelikheid van 'n ondememing vir sy optrede in die omgewing waarin sake bedryf word. Die resultate van 'n onderneming se optrede in die konteks van sosiale verantwoordelikheid word in sosiale verslaggewing aan belanghebbende partye gerapporteer. Hierdie soort verslae het weens 'n klemverskuiwing ten opsigte van die rol van maatskappye in die gemeenskap ontstaan en word vervolgens kortliks uiteengesit.

\section{Klemverskuiwing ten opsigte van die rol van maat- skappye}

Ondernemings het weens hul direkte betrokkenheid by die omgewing waarin hulle funksioneer, ook 'n direkte invloed op die welstand van die omgewing. Daar kan ook in sekere omstandighede aanvaar word dat 'n onderneming 'n leidende rol in die gemeenskap speel.

'The Corporate Report' (1975: 15) maak melding van die voogdelike ('custodial') rol van die onderneming in die gemeenskap.

Volgens Estes (1976: 1) ontdek die bestuur van ondernemings toenemend dat die maksimisering van 'n opbrengs aan aandeelhouers nie 'n genoegsame doelwit vir 'n onderneming is nie. Die gemeenskap verwag meer van ondernemings en dwing hul verwagting af met wetgewing en met druk op ondernemings. Gilchrist en Taylor stem hiermee saam:
'Indeed the current emphasis on employee participations and the importance of providing opportunities for employees to influence the decision-making process, are tacit acceptance that duties are owed not only to the owners' (1979: 558).

Ook Morley (1978[b]: 31) verwys dat daar 'n klemverskuiwing van die welvaart van aandeelhouers na dié van die gemeenskap plaasvind.

Die klemverskuiwing in die optrede van die onderneming veroorsaak noodgedwonge dat daar ook 'n verandering in dic verslaggewing van die aktiwiteite van die onderneming sal plaasvind.

\section{Ontwikkeling van sosiale verslaggewing}

Volgens Carrol (1977: 8-11) het die sosiale verantwoordelikheid en die gepaardgaande verslaggewing van bestuurders deur drie verskillende ontwikkelingsfases gegaan. Die fases word kortliks beskryf.

\section{Fase 1: Winsmaksimeringsbestuur}

Die grondslag van die winsmaksimiseringsfase kan in Adam Smith se werk 'The wealth of nations' gevind word. Hierdie fase het gedurende die negentiende en vroeg twintigste eeu plaasgevind. Gedurende hierdie fase was die optrede van maatskappye slegs deur wetlike vereistes beperk. Geen aandag is aan die stilswyende of uitdruklike vereistes van die gemeenskap oor die optrede van die onderneming geskenk nie, tensy dit wetlik vereis is. Adam Smith het geredeneer dat die welvaart van 'n gemeenskap die som van die welvaart van individue is. Die vermeerdering van die welvaart van enige groep lei gevolglik to vergrote rykdom van die totale gemeenskap. Volgens Adam Smith is dit dus tot die voordeel van die hele gemeenskap indien 'n ondernemer maksimum wins en dus sy eie voordeel najaag.

Volgens Carrol het die situasie soos dit in die voorafgaande paragraaf uiteengesit is, gelei tot 'n aantal ongewenste praktyke:

'In the process, employee abuses such as child labor, starvation wages, and unsafe working conditions could be tolerated' (1977: 8).

As gevolg van hierdie beskouing van die gemeenskap, is daar ook min aandag aan die bewaring van hulpbronne en die bewaring van die omgewing geskenk.

\section{Fase 2: Trusteeskapbestuur}

Gedurende hierdie fase, wat van 1920 tot 1930 geduur het, is bestuur nie slegs vir die maksimisering van die rykdom van aandeelhouers verantwoordelik gehou nie, maar ook vir die handhawing van 'n balans tussen die eise van kliènte, werknemers, verskaffers, krediteure, die gemeenskap en aandeelhouers. Hierdie pligte het dus die rol van die bestuurder eerder na dié van trustee verander. Dit was ook gedurende hierdie tydperk dat vakbonde as prominente drukgroep van die onderneming na vore getree het.

\section{Fase 3: Lewenskwaliteitsbestuwr}

$\mathrm{Na}$ die fase van trusteeskapbestuurder het die lewenskwaliteitsfase ontwikkel. Hierdie fase het veral in die ontwikkelde Westerse Wêreld ontwikkel waar die voorsiening 
in basiese behoeftebevredigende middele soos kos en dienste nie meer vir die brex gemeenskap 'n fundamentele probleem is nie. Hierdie sukses het egter direk sowel as indirek aanleiding gegee tot ander sosiale probleme soos die verswakking van die natuurlike hulpbronne asook die gemeenskap as 'n geheel.

Die lewenskwaliteitsfase bring nuwe doelwitte en die gemeenskap verwag dat ondernemings, met hul tegnologiese, bestuurs- en finansiěle vermoëns, groter verantwoordelikhede moet aanvaar. Faul, Everingham, Redelinghuys en Van Vuuren som die situasie soos volg op:

'There is an increasing agreement in society that management must accept responsibility for the consequences of the effects of the activities of their businesses on the community and environment' (1984: 493).

Dit kom daarop neer dat ' $n$ ondememing in die $\alpha$ van die gemeenskap as sosiaal verantwoordelik beskou word indien hy by die oplossing van die gemeenskap se probleme beurokke raak.

\section{Komponente van sosiale verslaggewing}

Behalwe vir die inligting wat wetlik in finansiěle verslae vereis word, verwelkom die gebruikers van die finansiële verslae enige verdere inligting wat die verstaanbaarheid en interpretasie van die state help verhoog. Volgens 'The Corporate Report' (1975: 47) word hierdie inligting ook gebruik om meer volledig verslag te doen oor die aanwending van hulpbronne in die ondememing. Hierdie hulpbronne sluit beide natuurlike en menslike hulpbronne in.

Die inhoud van sosiale verslae bevat gewoonlik kommentaar oor die onderneming se optrede in sosiale verantwoordelikheidsprogramme. Die aktiwiteite waaroor daar gewoonlik verslag gedoen word, kan opsommend in die volgende afdelings verdeel word (Faul, et al., 1984; Estes, 1976).

\section{Omgewing}

Verslaggewing oor die omgewing handel hoofsaaklik oor dic ondememing se bydrae tot die beheer van besoedeling, ander bewaringsaksies en ondersteuning verleen, energiebesparing en herbenutting van grondstowwe.

\section{Werknemers}

Verslae or werknemers handel oor veral werwing, opleiding en bevordering van werknemers in die onderneming. Daar word ook gereeld in die verslae verwys na gesondheids- en veiligheidsomstandighede, vergoeding van personeel, pensioene en verlofvoordele. Belkaoui (1985: 409) verwys ook na ander inligting soos die aantal werknemers, die ouderdomsverspreiding van werknemers en die vakbonde wat deur die onderneming erken word vir insluiting onder hierdie afdeling van sosiale verslaggewing.

\section{Produkte}

Verslaggewing oor produkte dek ondermeer die onderneming se produkkwaliteit en -veiligheid, opvoeding van gebruikers en produkwaarborge en -navorsing. Hierdie verslae word primêr op die verbruiker gerig.

\section{Gemeenskap}

Die verslae oor die onderneming se gemeenskapsbetrokkenheid meld onder andere die hulpdienste wat die ondememing aan die gemeenskap lewer. Dit sluit voordele soos behuising, gesondheidsdienste, vervoer en donasies aan liefdadigheid in.

Die fasette van sosiale verslaggewing wat hierbo genoem is, kan op twee maniere aangebied word. Die inligting oor die onderneming se sosiale optrede kan enersyds by finansièle verslae ingesluit word of as 'n volledige verslag van die inligting oor sosiale optrede as 'n outonome verslag aangebied word. Die aanbieding van die sosiale verslag sal hoofsaaklik afhang van wat die doel van bestuur is met die verslag.

\section{Staat van toegevoegde waarde en eksteme finan- slele verslaggewing}

Uit hoofde van die verandering wat in verslaggewing van verskeie ondernemings ingetree het, stel 'The Corporate Report' (1975: 48) die volgende verslae aanvullend tot die huidige statutêr-vereiste inligting voor:

- 'n Staat van toegevoegde waarde wat die verdeling van die welvaart wat binne 'n ondememing geskep is, aandui.

- 'n Werknemersverslag met die aantal en samestelling van die werkerkorps en die voordele wat aan werknemers gegee is.

- 'n Staat van transaksies in buitelandse valuta wat aandui wat die volume van buitelandse transaksies van die ondememing was.

- 'n Staat van toekomstige geleenthede van die onderneming wat toekomstige winste, indiensneming en kapitaalinvestering insluit.

- 'n Uiteensetting van die ondememing se strategiese doelwitte.

Dit is dus duidelik dat die staat van toegevoegde waarde uit hoofde van veranderende verslaggewing ontstaan het. Die vraag kan egter ontstaan of maatskappye die staat van toegevoegde waarde in hul finansiële jaarverslae insluit as gevolg van 'n behoefte aan vereenvoudigde verslaggewing van die meerderheid gebruikers of potensiële gebruikers van die verslae, en of die staat van toegevoegde waarde 'n deel van 'n sosiale verslaggewingsprogram is. Die insluiting van die staat kan in die derde plek ook gebaseer wees op die verhoogde inligtingswaarde en die ekonomiese realiteit en vergelykbaarheid wat met die staat bereik kan word.

Indien aanvaar word dat die staat van toegevoegde waarde op grond van 'n behoefte aan vereenvoudigde verslaggewing gepubliseer word, is dit noodsaaklik dat die inligting van sulke verslae redelik maklik met die statutêr-vereiste inligting versoenbaar moet wees. In die geval van 'n bydrae tot sosiale verslaggewing, kan maatskappye egter poog om die winsbejag van die maatskappy te verdedig. In hierdie verband word verwys na 'n aanhaling uit Huggins:

'The statements in several company reports ... seem to contain more than a hint of apology for having made profits. In every case there is an attempt to minimise the significance of profits (and especially dividends) by placing the figures in close proximity to the much 
larger salaries and wages figures... At best this becomes an attempt to justify the existence of business by emphasising the wealth created' (1980: 141).

Die logiese gevolgtrekking uit die bostaande aanhaling is dat die staat van toegevoegde waarde nie alleen met sosiale verslaggewing verband hou nie, maar ook 'n direkte verband met verslaggewing van werknemers het. Schuitema stem saam met hierdie standpunt:

'The Value Added Statement has emerged as a very crucial and appropriate response to workforce misconceptions' (1988: 338).

In suiwer Suid-Afrikaanse verband is Stobie (1986: 344) van mening dat die grootste bydrae van die staat van toegevoegde waarde die oplossing van konflik oor die verdeling van fondse tussen bestuur en werkers is. Ook hierdie siening dui dus op die gebruik van die staat van toegevoegde waarde vir doeleindes van die werknemers. Dit beteken dus dat die insluiting van allerlei addisionele items, soos byvoorbeeld voorsiening vir inflasie en groei, in die staat genoodsaak word om die wenslikheid van sekere retensies van toegevoegde waarde te benadruk. Werkers behoort daarom nie ten tye van loongeskille uit onkunde op die resterende gedeeltes van toegevoegde waarde aanspraak te maak nie.

Sou daar aanvaar word dat die staat van toegevoegde waarde uit hoofde van die verhoogde inligtingswaarde van die items van die staat ontwikkel het, moet die waarde van die addisionele inligting van die staat ondersoek word. Dit sal bepaal of die inligting van die staat genoegsame bydrae tot tradisionele finansiële inligting lewer om die insluiting van die staat in finansiële verslae te regverdig.

\section{Die konsep: Toegevoegde waarde}

Die konsep van togevoegde waarde verwys na die rykdom ('wealth') wat 'n ondememing met eie pogings en dié van werknemers skep ('The Corporate Report', 1975: 49). Volgens Bentley (1981: 17) verteenwoordig toegevoegde waarde die toename in die waarde van hulpbronne van 'n onderneming deur die aanwending van kennis en menslike vernuf in die onderneming. Kruger (1988: 1) verwys na die totale toegevoegde waarde wat binne 'n ekonomie geskep is as die 'groei' wat gedurende die tydperk behaal is.

Toegevoegde waarde is ook gelyk aan '... the amount of productive effort contributed by a business from its own resources towards its sales output' (Renshall, Allan en Nicholson, 1979: 11). Laasgenoemde skrywers benadruk die feit dat toegevoegde waarde uit eie aktiwiteite ontstaan. 'Added value concentrates exclusively on a business's ... direct operating income and expenses ...' (Renshall, et al., 1979: 11). Dit is juis hierdie feit wat toegevoegde waarde van inkomste onderskei. Toegevoegde waarde dui op die totale welvaart wat in die onderneming tot voordecl van alle betrokke partye geskep is, terwyl inkomste bloot op die netto resultaat van 'n tydperk se aktiwiteite dui. Hutching en Stone (1984: 262) sê dat wins die netto resultaat van al die aktiwiteite van die ondememing is, terwyl toegevocgde waarde slegs aandag skenk aan wat binne die ondememing gebeur. Die bestuur van 'n onderneming behoort volgens hierdie skrywers te konsentreer op daardie dinge waaroor hulle die meeste beheer het (dit wil sê toegevoegde waarde). Morley (1978[a]: 3) maak melding van '... the cooperative efforts by shareholders, lenders, workers and the Government' in die geval van toegevoegde waarde. Volgens Morley is inkomste slegs 'n gedeelte van die brex toegevoegde waarde vir 'n jaar.

Daar bestaan twee fundamentele konseptuele berekeningswyses vir die berekening van toegevoegde waarde. Toegevoegde waarde kan in die eerste plek beskou word as die verskil tussen die bruto ontvangste van 'n onderneming uit die verkoop van goedere en dienste en die bedrag wat vir die aankoop van grondstowwe en dienste van verskaffers buite die ondememing betaal is (Renshall, et al., 1979: 1). Hierdie benadering omskryf toegevoegde waarde volgens die ontstaan daarvan in die onderneming. Die tweede benadering ten opsigte van die definiëring van toegevoegde waarde fokus op die verdeling van die welvaart wat binne die onderneming geskep is. Huggins (1980: 141) gebruik hierdie benadering wanneer hy toegevoegde waarde gelyk stel aan die som van salarisse en lone, rente op geleende kapitaal en die surplus wat aan die eienaars van die onderneming behoort. Burns (1978: 93) verwys na die 'mutuality of interest' wanneer hy die samewerking tussen die verskillende groepe wat tot die skepping van toegevoegde waarde bydra, beskryf.

\section{Samestelling van die staat van toegevoegde waarde}

Uit die omskrywings van toegevoegde waarde in die voorafgaande paragrawe, blyk dat die staat van toegevoegde waarde 'n uiteensetting is van die komponente wat in 'n onderneming tot die skepping van toegevoegde waarde bygedra het. Die staat dui ook aan watter vergoeding elke komponent gedurende die betrokke tydperk ontvang het. In 'The Corporate Report' word dit soos volg gestel:

'The simplest and most immediate way of putting profit into proper perspective vis a vis the whole enterprise is by the presentation of a statement of value added...' (1975: 49).

Volgens Gilchrist en Taylor (1979: 562) bevat die staat van toegevoegde waarde aanvullende finansiële inligting. Hierdie staat vervang egter geensins konvensionele rekeningkundige inligting nie. Inligting wat in 'n staat van toegevoegde waarde voorkom, is hoofsaaklik 'n herstrukturering van syfers wat reeds in die inkomstestaat voorkom. Hierdie twee state is egter nie inhoudelik dieselfde nie. Die staat van toegevoegde waarde dui alle elemente wat tot die skepping van toegevoegde waarde bygedra het asook vergoeding wat vir die bydrae betaal is, onafhanklik aan (Woolf 1979: 135). Die staat van toegevoegde waarde word dus nie uit die oogpunt van enige spesifieke belangegroep opgestel nie. In teenstelling hiermee druk die inkomstestaat die resultate van die verslagdoeningstydperk hoofsaaklik in terme van die voordeel of nadeel van aandeelhouers uit (Stobie, 1986: 341).

In Tabel 1 word 'n aangepaste voorbeeld van die staat van toegevoegde waarde soos voorgestel deur Rossler en Gourley (1983: 223) gegee. 
Tabel 1 ' $n$ Tipiese voorbeeld van 'n staat van toegevoegde waarde

ABC Beperk

Staat van toegevoegde waarde vir die jaar geëindig 31 Desember $19 \times 2$

\begin{tabular}{|c|c|c|c|c|}
\hline & \multicolumn{2}{|c|}{$19 \times 2$} & \multicolumn{2}{|c|}{$19 \times 1$} \\
\hline & RAND & $\%$ & RAND & $\$$ \\
\hline Onset & 1000 & & 900 & \\
\hline Min: Ingekoopte goedere en dienste & 370 & & 360 & \\
\hline Waardevermindering & 30 & & 20 & \\
\hline Toegevoegde waarde & 600 & 100 & 520 & 100 \\
\hline \multicolumn{5}{|l|}{ Aangewend soos volg: } \\
\hline \multicolumn{5}{|l|}{ Vergoeding aan werknemers: } \\
\hline Salarisse, lone en ander voordele & 300 & 50 & 230 & 44 \\
\hline \multicolumn{5}{|l|}{ Vergoeding aan kapitaalverskaffers: } \\
\hline Rente op lenings & 50 & 8 & 50 & 10 \\
\hline Dividende aan aandeelhouers & 50 & 8 & 45 & 9 \\
\hline \multicolumn{5}{|l|}{ Vergoeding aan owerheid: } \\
\hline Maatskappybelasting betaal & 100 & 17 & 90 & 17 \\
\hline \multicolumn{5}{|l|}{ Voursiening vir uitbreiding } \\
\hline Onaangewende inkomste & 100 & 17 & 105 & 20 \\
\hline Waarde togedeel & 600 & 100 & 520 & 100 \\
\hline
\end{tabular}

Bron: Aangepas uit Rossler en Gourley (1983: 223)

Volgens Roullier (1978: 99) behoort alle persone wat direk vir hulle dienste vergoed word, by die staat van toegevoegde waarde uitgesluit te word. Die staat behoort egter aan te dui hoe inkomste tussen alle persone wat by die bedryf en voortsetting van die onderneming betrokke is, verdeel word. Roullier verdeel die lede van die span wat vir die skepping van toegevoegde waarde verantwoordelik is, in die volgende breë groepe:

- Werknemers wat van die onderneming afhanklik is vir toekomstige indiensneming, inkomste en pensioenvoordele.

- Gewone aandeelhouers wat die risikokapitaal verskaf en die voordeel geniet indien die onderneming suksesvol is.

- Die owerheid wat bydra om 'n bedryfsomgewing te skep waarbinne die onderneming doelureffend kan funksioneer.

Morley (1978[a] : 26) sluit ook die kredietverleners van die onderneming onder die bree hofie van kapitaalverskaffers in.

\section{Staat van toegevoegde waarde en die verelstes van finansiêle verslaggewing}

Dic doel van dic staat van toegevoegde waarde is om die finansiële verslae van maatskappye aan te vul en uitcindelik meer bruikbare verslae voort te bring. Teen hierdic agtergrond is dit noodsaaklik dat die staat van toegevoegde waarde wat in die voorafgaande bespreck is, aan die hand van die vereistes van finansiële verslaggewing, getoets word. Vervolgens word 'n kort bespreking gegee van die staal van toegevoegde waarde aan die hand van hierdie vereistes (Alexander, 1986: 64-65; Hendriksen, 1982: 505; en 'The Corporate Report', 1975: 28-29).

\section{Regverdigheid}

Die staat van toegevoegde waarde het ten doel om alle gebruikers van finansiěle verslae gelyk te behandel. In hiendie opsig vul hierdie staat die huidige vereiste komponente van finansiële verslae aan aangesien die bestaande komponente veral klem lê op die belange van aandeelhouers.

\section{Tersaaklikheid}

Die staat van toegevoegde waarde verskaf addisionele inligting en is veral op die inligtingsvereistes van die oningeligte gebruiker van finansiële verslae ingestel. Dié inligting bestaan veral uit die vergoeding van werknemers en die persentasieverdelings van die verskillende items van die totale verdeling van toegevoegde waarde. Die uitgangspunt is juis dat die staat van toegevœegde waarde uit hoofde van 'n behoefte aan vereenvoudigde verslaggewing ontstaan het. Uit die oogpunt van ontleders van finansiêle verslae spruil daar ook 'n hoeveelheid inligting voort. Voorbeelde hiervan is veral sekere inter-maatskappyvergelykings van 'n antal verhoudingsgetalle met toegevoegde waarde en ander items van die staat.

\section{Verstaanbaarheid}

Die vereenvoudigde uiteensetting en die maklike rekonsilieerbaarheid van die staat van toegevoegde waarde het juis ten doel om die staat so verstaanbaar as moontlik vir die gebruiker van die staat te maak.

\section{Betroubaarheid}

Die inhoud van die staat word so opgestel dat die items van die staat, met die uitsondering van ingekoopte goedere en dienste en werknemersvergoeding, maklik uit bestaande finansiële inligting gekontroleer kan word. Indien die oudit van die staat in die toekoms verplig sou word, sal dit verder tot die betroubaarheid van die staat bydra.

\section{Volledigheid}

Die beskikbaarheid van die inligting wat in die staat van toegevoegde waarde vervat word, dra tot 'n volledige uiteensetting van die finansiële aktiwiteite en situasie van die onderneming by deurdat dit inligting aanvullend tot dié van ander state verskaf.

\section{Objektiwiteit}

Indien aanvaar word dat die staat van toegevoegde waarde in die toekoms aan oudit onderwerpe sal word en dat die inhoud van die staat deur 'n standaard van die rekeningkundige professie gereguleer sal word, sal die inhoud van die staat nie deur die persepsie van enige enkele belangegroep beïnvloed kan word nie. Die staat sal dus ook nie die belange van enige enkele belangegroep kan bevoordeel nie.

\section{Tydigheid}

Die insluiting van 'n staat van toegevoegde waarde behoon nie werklik to 'n vertraging in die beskikbaarstelling van die gepubliseerde finansiële verslae te lei nie. Die rede hiervoor is dat die inligting wat addisioneel vir die staat van toegevoegde waarde benodig word, waarskynlik met groot 
gemak uit die inteme rekeningkundige bronne van die onderneming verkry kan word.

\section{Vergelykbaarheid}

Hierdie vereiste maak ook voorsiening vir die toepassing van algemeen aanvaarde standaarde, dit wil sê dat die inhoud van die staat aan oudit onderwerp kan word. Indien daar wel aan hierdie vereiste voldoen word, sal die vereiste van vergelykbaarheid nagekom kan word deurdat dit vergelykings tussen die syfers van verskillende maatskappye en tussen verskillende jare se resultate van dieselfde maatskappy tot gevolg sal hê.

\section{Metodologie}

Die metodiek van die empiriese studie kan in twee bree groepe verdeel word. Daar is in die eerste plek van 'n posvraelys aan genoteerde maatskappye gebruik gemaak, terwyl die state van toegevoegde waarde van maatskappye wat onder die nywerheidsektor op die Johannesburgse Effektebeurs genoteer is, in die tweede plek ondersoek is. Die laasgenoemde ondersoek kan in drie dele verdeel word. In die eerste plek is ' $n$ ondersoek na die aanbieding deur maatskappye van die staat van toegevoegde waarde as geheel en per individuele item geloods. Hierna is die oorspronklike inhoud van die state van toegevoegde waarde van die maatskappye wat ondersoek is, volgens 'n voorgestelde uitleg van die staat aangepas om die verandering op die oorspronklike syfers te bereken. Die ondersoek na die state van toegevoegde waarde van maatskappye is in die derde plek afgesluit met die berekening van enkele belangrike finansiële verhoudingsgetalle met toegevoegde waarde binne 'n enkele bedryfstak. Hierdie verhoudingsgetalle is bereken met die oog op vergelykings tussen die resulterende verhoudingsgetalle van die maatskappye binne die bedryfstak.

\section{Posvraelys}

Altesaam 112 vraelyste is na maatskappye wat op die Johannesburgse Effektebeurs onder die nywerheidsektor genoteer is, uitgestuur. Al 52 vraelyste wat terugontvang is, was bruikbaar wat 'n responskoers van $46,4 \%$ verteenwoordig. Vraelyste is gestuur aan alle maatskappye wat volgens die rekords van die Nagraadse Bestuurskool van die Universiteit van Stellenbosch vir die 1988-finansièle jaar state van toegevoegde waarde gepubliseer het. Die rekorddatum was die einde van Januarie 1989. Hierdie lys is aangevul met maatskappye wat state van toegevoegde waarde gepubliseer het maar nie in die eersgenoemde lys voorgekom het nie, en waarvan die 1988-jaarverslae reeds op 5 April 1989 deur die Departement Bedryfsekonomic van die Universiteit Vista ontvang is. Alhoewel hierdie lys nie die name van alle maatskappye bevat nie, is 5 April 1989 as die afsnydatum vir die samestelling van hierdie lys gebruik. Hierdie afsnypunt is gebruik sodat die tydsverloop vanaf die versending van die vraelyste tot die bekendmaking van die resultate van die ondersoek, so kort moontlik gehou kon word. Hiermee is gepoog om die resultate van die ondersoek ten tye van die bekendmaking daarvan, so relevant moontlik te maak.

\section{Ondersoek van finansiêle jaarverslae}

Die 1988-state van toegevoegde waarde van 130 maatskappye wat onder die nywerheidsektor op die Johannesburgse Effektebeurs genoteer is, is vir doeleindes van die empiriese ondersoek ontleed. Die lys van name van die maatskappye wat by die ondersoek betrek is, is saamgestel uit die rekords van die Universiteit Vista en die Nagraadse Bestuurskool van die Universiteit van Stellenbosch. Hierdie name is gekontroleer en aangevul met die hulp van rekords van die Buro vir Finansiële Analise van die Universiteit van Pretoria wat tot en met 8 Junie 1989 beskikbaar was. Alhoewel daar volgens die rekords van die Buro vir Finansiele Analise tot op 31 Januarie 1990 'n totaal van 150 maatskappye in die nywerheidsektor was wat in 1988 state van toegevoegde waarde gepubliseer het, is enige finansièle jaarverslae wat na die afsnydatum van 8 Junie 1989 beskikbaar geword het, vir doeleindes van hierdie studie buite rekening gelaat. Die rede vir die afsnypunt is dat die tydsverloop vanaf die jaarafsluiting tot die datum waarop die laaste finansièle verslae ontvang is, so kort moontlik gehou is sodat die bevindinge van die ondersoek steeds relevant sal wees ten tye van die bekendmaking van die resultate.

\section{Bevindinge}

Vanuit die teoretiese onderbou en die bevindinge van die empiriese studie kan die volgende gevolgtrekkings gemaak word rakende die staat van toegevoegde waarde as komponent van finansiële verslaggewing in Suid-Afrika.

\section{Bevindinge van die posvraelys}

- Maatskappye in Suid-Afrika publiseer nie die staat van toegevoegde waarde vir die doeleindes van aandeelhouers nie. In hierdie opsig wyk die staat van toegevoegde waarde af van konvensionele komponente van finansiele verslae wat primêr op die behoeftes van aandeelhouers ingestel is.

- Die staat van toegevoegde waarde het nie die inligtingsbehoeftes van krediteure of dié van werknemers en hul verteenwoordigers as doelwit nie. Alhoewel die literatuurstudie die inligtingsbehoeftes van die werknemers van maatskappye as een van die primêre oogmerke van die staat van toegevoegde waarde aandui, het die empiriese ondersoek getoon dat maatskappye ook nie die staat vir hierdie groep se voordeel publiseer nie.

- Dit blyk uit die respons wat ontvang is dat die staat van toegevoegde waarde nie uit hoofde van sosiale verslaggewing gepubliseer word nie.

- Die opname het getoon dat maatskappye neutraal staan teenoor die bestaansreg van toegevoegde waarde. Hierdie toedrag van sake kan volgens die outeurs vertolk word dat nóg die staat van toegevoegde waarde nóg die konsep van toegevoegde waarde deur die deelnamegroep as relevant beskou word en daarom nie van belang is nie.

- Volgens die empiriese ondersoek beskou maatskappye nie die inligtingsbehoeftes van eksterne analiste as belangrik wanneer die staat van toegevoegde waarde gepubliseer word nie. Indien die behoeftes van analiste nie vir maatskappye van belang is nie, en in die lig daarvan 
dat slegs 'n enkele respondent (1,9\% van die respondente) aangedui het dat toegevoegde waarde intern vir produktiwiteitsmeting gebruik word, kan daar ook twyfel bestaan of die maatskappye toegevoegde waarde vir interne analises gebruik.

- Die opname het oorwegend getoon dat maatskappye nie 'n staat van toegevoegde waarde in finansièle jaarverslae insluit vir toekennings vir goeie finansiële verslae nie. Hierdie situasie kan tweërlei vertolk word. Daar kan enersyds geredeneer word dat, indien die staat van toegevoegde waarde nie vir die voordeel van enige van die teikengroepe gepubliseer word nie, die staat slegs met die oog op die jaarlikse toekennings vir finansiële verslae beskikbaar gestel word. In hierdie geval sou dit dus beteken dat die respondentegroep nie die ware toedrag van sake wou bekendmaak nie. Andersyds beteken dit dat, indien maatskappye state van toegevoegde waarde gepubliseer het maar geen doel met die staat aangedui het nie, die maatskappye nie die gebruikswaarde van die staat verstaan of erken nie. Die Buro vir Finansiële Analise en die Instituut vir Geoktrooicerde Rekenmeesters ken wél 'n aantal punte vir die insluiting van 'n staat van toegevoegde waarde toe wanneer dic jaarverslae van maatskappye beoordeel word en dit kan veroorsaak dat maatskappye dic staat van toegevoegde waarde bloot vir hierdie doel in hul jaarverslae insluit. Die outeurs is dus van mening dat die meerderheid van die respondentegroep die staat van toegevoegde waarde moontlik slegs met die oog op jaarlikse toekennings publiseer.

- Die respondentegroep wat reeds die reaksie van die teikengebruikers van die staat van toegevoegde waarde op die inhoud daarvan getoets het, is waarskynlik te klein (slegs $13,5 \%$ van die respondente) om enige gevolgtrekkings oor die aanvaarbaarheid van die staat vir die teikengroepe te makk. Dit is nogtans betekenisvol dat so in klein persentasie van die respondentegroep reeds die reaksie op die staat getoets het. Aangesien die staat van toegevoegde waarde nie statutêr vereis word nie, kan aanvaar word dat die staat slegs in finansiële verslae ingesluit word indien dit tot die voordcel van 'n belanghebbende groep sou strek. Dit is egter duidelik dat die meerderheid van die respondentegroep nog nie probeer bepaal het of die staat wel aan die behoeftes of verwagtinge van die teikengebruikers voldoen nie. Dit wil voorkom asof die grootste deel van die declnemende groep die staat van toegevoegde waarde ò met die oog op jaarlikse tockennings publiseer òf dat dic staat as poging tot vereenvoudigde finansięle verslaggewing ingesluit word.

- Die resultate van die ondersoek toon dat die meeste van die respondente die verpligte insluiting van die staat van toegevoegde waarde in finansiële verslae, die behoefte aan 'n standaarduitleg en -samestelling van die staat en die verpligte ouditering van die staat as onbelangrik beskou. Dit blyk daarom dat die insluiting van die staat per se nie werklik vir die maatskappye van belang is nie. 'n Verdere gevolgtrekking wat hieruit gemaak kan word, is dat maatskappye verkies dat die insluiting van die staat in jaarverslae vrywillig moet wees en aan so min as moonulik voorskrifte moet voldoen. Hierdie situasie laat egter die geleentheid aan maatskappye om die inhoud van die state binne redelike perke na gelang van hulle eie doel met die staat aan te pas. Dit veroorsaak ook dat daar geen basis van vergelyking van resultate tussen verskillende maatskappye en bedryfstakke bestaan nie.

\section{Bevindinge van die ondersoek van state van toege- voegde waarde}

- Dit blyk uit die ondersoek dat die meeste maatskappye die aanbieding van die staat van toegevoegde waarde met 'n persentasieverdeling van toegevoegde waarde aanvul, terwyl 'n skematiese voorstelling van die verdeling in die meerderheid van die gevalle voorgekom het. Daar word dus 'n doelbewuste poging deur die maatskappye waarvan state ondersoek is, aangewend om die inhoud van die staat vir gebruikers van die staat meer verstaanbaar te maak. Dit volg dus dat die aanbieding van die staat op die behoeftes van die oningeligte gebruikers van finansiële verslae gemik is.

- Die oorgrote meerderheid van die state van die maatskappye wat ondersoek is, het van die bruto-metode van berekening van toegevoegde waarde gebruik gemaak. Dit beteken dat die meeste van die maatskappye die voorbeeld van die staat wat in 'The Corporate Report' (1975) verskyn, volg. Hierdie standpunt kan egter nie sonder meer aanvaar word nie. Die algemeenste kritiek teen die bruto-metode, is dat waardevermindering beskou moet word as die vergoeding vir die gebruik van ' $n$ bate by die skepping van welvaart. Sou 'n bate deur middel van 'n bruikhuur gefinansier word of deur verhuring bekom word, dan sal die vergoeding vir die gebruik van die bate outomaties as ingekoopte goedere en dienste beskou word. Die blote feit dat 'n onderneming verkies om 'n bate aan te koop en daarom waardevermindering daarop kan afskryf, verander nie die aard van die aanwending van die bate nie. Die feit dat die meeste ondememings die bruto-metode aanvaar, vrywaar hulle dus nie van die konseptuele argumente wat teen hierdie metode uitgespreek word nie.

- Alhoewel die meerderheid van die maatskappye wat ondersoek is Algemene Verkoopsbelasting (AVB) by die omsetsyfer uitgesluit het, was daar nogtans 'n aantal maatskappye wat AVB by die omset ingetel het. Dit beteken dat, selfs al is daar weinig regverdiging vir die insluiting van AVB in omset, sommige maatskappye steeds die geleentheid benut om in die lig van die afwesigheid van 'n standaardaanbieding van die staat, die inhoud van die staat volgens hulle eie doel met die staat aan te pas.

- Die naam van die staat wat in 'The Corporate Report' (1975) voorgestel is, naamlik 'Value Added Statement' of 'Staat van Toegevoegde Waarde' word deur die meeste maatskappye aanvaar.

- Die toepassing van 'n standaarduitleg en -samestelling van die staat van toegevoegde waarde op die oorspronklike state van die maatskappye wat ondersoek is, het by sommige maatskappye 'n vermindering van $50 \%$ van die gepubliseerde toegevoegde waarde tot gevolg gehad, terwyl dit in ander gevalle 'n styging van tot $17 \%$ in toegevoegde waarde veroorsaak het. Dit beteken dat die inligting wat in die oorspronklike state van toegevoegde 
waarde vervat is, geensins tussen maatskappye vergelyk kan word nie tensy die resultate na 'n standaarduitleg omgeskakel word. Sonder die aanwesigheid van 'n standaard vir die aanbieding van die staat het die inhoud daarvan dus min waarde vir sommige van die gebruikersgroepe aangesien dit vergelyking met soortgelyke of ander maatskappye onmoontlik maak.

- Dit blyk uit die ondersoek dat dit moontlik is om sinvolle finansiële verhoudingsgetalle met toegevoegde waarde te bereken, alhoewel die verhoudings slegs sinvol geïnterpreteer kan word indien dit in samehang met 'n totale finansiële ontleding geskied. Indien vergelykings tussen maatskappye in dieselfde bedryfstak gemaak word, sal 'n analise van ander faktore soos finansieringsmetodes en kapitaalintensiteit ook in die analise in aanmerking geneem moet word.

Ter samevauting kan dus beweer word dat, alhoewel die staat van toegevoegde waarde wel volgens die literatuurstudie bestaansreg en analisemoontlikhede het, dit uit die empiriese ondersoek blyk dat die staat van toegevoegde waarde nie vir hierdie doel deur maatskappye gepubliseer word nie.

\section{Aanbevellings}

'n Groot aantal van die maatskappye wat onder die nywerheidsektor van die Johannesburgse Effektebeurs genoteer is, publiseer reeds 'n staat van toegevoegde waarde. Die empiriese ondersoek toon egter dat die staat van toegevoegde waarde nie vir die gebruik van enige spesifieke groep gebruikers van finansiële verslae gepubliseer word of dat die inligting vir ontledings binne die maatskappye gebruik word nie. In die lig van die onderbenutting van die staat van toegevoegde waarde, word die volgende aanbevelings gemaak:

- Die staat van toegevoegde waarde sal slegs ten volle benut word indien dit die behoeftes van die gebruikers van die staat aanspreek. Die inhoud en aanbieding van die staat soos dit tans deur maatskappye aangebied word, word egter deur die persone wat verslag doen, bepaal. Teen hierdie agtergrond kan die staat van toegevoegde waarde meer aanvaarding geniet indien die inhoud van die staat volgens die behoeftes van die bestaande en potensièle gebruikers van die staat opgestel word. Om hierdie rede word aanbeveel dat 'n ondersoek onder gebruikers van die staat geloods word om die mees gewenste aanbieding van die staat vas te stel.

- Die huidige onvergelykbaarheid tussen maatskappye ten opsigte van die aanbieding van die staat van toegevoegde waarde in finansiële jaarverslae veroorsaak dat die staat min toepassingsmoontlikhede vir verskeie potensiële gebruikersgroepe van die staat het. Daar is gevind dat daar groot afwykings is tydens die omskakeling van die oorspronklike inligting van state van toegevoegde waarde na 'n standaarduitleg. Daar is dus afdoende bewys dat maatskappye die staat op vergelykbare wyse moet aanbied indien die staat enigsins vir inter-maatskappyvergelykings gebruik wil word. In die lig hiervan word aanbeveel dat die staat steeds in jaarverslae gepubliseer word, maar dat 'n standaard vir die aanbieding van die staat vereis word.
Samevattend kan daar dus aanbeveel word dat die staat van toegevoegde waarde steeds in die jaarverslae van maatskappye gepubliseer word, maar dat dit so aangebied word dat die inhoud van die staat vir die gebruikers van die staat nuttig sal wees.

\section{Voorstelle vir verdere navorsing}

Aan die hand van die ondersoek wat vir hierdie studie onderneem is, wil dit voorkom asof sekere aspekte van die staat van toegevoegde waarde in die konteks van finansiele verslaggewing verdere ondersoek regverdig. Die volgende ondersoeke word in hierdie verband voorgestel:

- Dit blyk noodsaaklik te wees om die reaksie van die gebruikers van finansiële verslae op die konsep van toegevoegde waarde en die staat van toegevoegde waarde in die huidige aanbiedingsvorm te bepaal. Aangesien finansiële verslae dit ten alle tye ten doel moet hê om die inligtingsbehoeftes van die gebruikers van die verslae te bevredig, beteken dit dat enige ontwikkeling in hierdie verband sinneloos sou wees indien dit nie op die behoeftes van die gebruikers gerig is nie.

- Die resultate van die empiriese ondersoek na die aanwending en die bruikbaarheid van finansielle verhoudingsgetalle met toegevoegde waarde toon dat sulke verhoudingsgetalle in die konteks van 'n volledige ontleding van finansiële state moet plaasvind. Hierdie studie het slegs oorsigtelik aan die aspek aandag geskenk en kon weens die strekwydte van die ontleding van die verhoudingsgetalle tot geen daadwerklike gevolgtrekking kom nie. Hierdie aspek behoort egter meer volledig nagevors te word en die nut van hierdie finansiële verhoudingsgetalle behoort meer volledig ondersoek te word.

\section{Summary}

Introduction

The publication of the value added statement (hereafter VAS) in South Africa in all probability originated from the recommendations for such a statement in 'The Corporate Report', published in the United Kingdom in 1975. This report suggested the inclusion of a VAS and other information such as an employee report in annual financial statements. The main purpose of the inclusion of this information is to accommodate the information needs of both the uninformed existing and potential users of financial information. It would therefore seem that the VAS is targeted at the uninformed employee and shareholder.

Although the South African Companies Act does not require a VAS in annual financial reports, numerous local companies have since 1977 included a VAS in their financial reports. As it seems obvious that companies publishing a VAS do so to accommodate one or more of the user groups of financial statements, the aim of this article was to determine to what end the statement is published and how the statement is compiled.

The methodology of the empirical study consisted of a postal questionnaire to listed companies and an analysis of the 1988 VAS of companies listed under the industrial sector of the Johannesburg Stock Exchange. The analysis of the statements consisted of three sections: 
a. An analysis of the presentation of the VAS and the calculation of individual items.

b. The adoption of the contents of the original information of the VAS according to a suggested layout of the statement to standardize the results of the various companies and to calculate the change from the original figures.

c. The calculation of certain financial ratios with value added for comparison between companies.

Results of the study

\section{Results of the questionnaire}

The following is a summary of the results of the questionnaire:

1. Respondents considered the needs of the theoretical target groups of the VAS i.e. shareholders and employees as the least important reasons for the publication of the statement.

2. The inclusion of the VAS for annual financial reporting awards and for the information needs of creditors were considered the most important reasons for the statement.

3. Only $14 \%$ of respondents have in any way tested the reaction of targets groups to the contents of VAS.

4. Most companies consider the compulsory inclusion and/or auditing and a standard for the layout of the VAS unimportant.

\section{Results of analysis of value added statements}

The results of the analysis of value added statements showed the following:

1. Most companies use the name 'Value Added Statement' for the statement and use the gross method of calculating value added. Most companies also supplement the distribution items of value added with percentages, while a graphic presentation was supplied in most cases.

2. The application of the standard layout of the VAS during the study resulted in changes of between $50 \%$ higher and $17 \%$ lower than the value added reported by various companies.

3. It seems that value added does allow for meaningful financial ratios to be calculated if done in the context of a total financial analysis.

\section{Conclusions}

The following conclusions can be drawn from the study:

1. Companies seem to include the VAS in financial reports for their own benefit and not that of users.

2. The non-availability of a standard lay-out of the VAS at present make inter-company comparisons impossible.

3. The information in the VAS can contribute to meaningful financial analysis.

\section{Recommendations}

The following recommendations are made following the study:
1. That an investigation be done into the needs of the various users of financial statements to determine the most desirable presentation of the statement.

2. That the statement be included in financial reports on a voluntary basis but be subjected to a standard outlay and composition.

\section{Verwysings}

Alexander, D. 1986. Financial reporting - a theoretical and regulatory framework. Worcester: Van Nostrand Reinhold Co. Led.

Belkaoui, A. 1985. Accounting Theory. Chicago: Harcoun Brace Jovanovich.

Bentley, T. 1981. Added value and contribution. Management Accounting, Vol. 59, No. 3, 17-21.

Burns, P. 1978. Do we need a new statement - cash value added? Accounting, July, 93-96.

Carrol, A.B. 1977. Managing corporale social responsibility. New York: Little, Brown and Company.

Du Plessis, A.P. 1987. Toegevoegde waarde in jaarverslae van Suid-Afrikaanse maatskappye: 'n Kort oorsig van die praktyk. S.-Afr. Tydsk. vir Bedryfsl, Vol.18, No. 4, 243-249.

Estes, R. 1976. Corporate social accounting. New York: John Wiley and Sons.

Faul, M.A., Everingham, G.K., Redelinghuys, H.F \& Van Vuuren, L.M. 1984. Financial accounting. Pretoria: Butterworths.

Gilchrist, R.R. \& Taylor, L.G. 1979. The future of company reports. Australian Accountant. September, 558-563.

Hendriksen, E.S. 1982. Accounting theory. Homewood, Illinois: Irwin.

Huggins, J. 1980. The value added statement - does it really add value? Accountants Journal. May, 140-142.

Hutching, C. \& Stone, D. 1984. Understanding Accounting! New York: Pitman.

Kruger, J.A.S. 1988. Staat van toegevoegde waarde. Staripsie ingelewer by die Nagraadse Bestuurskool van die Universiteit van Stellenbosch, Bellville.

Maatskappywet 61 van 1973.

Morley, M.F. 1978(a). The value added statement. A review of its use in corporate reports. London: Gee \& Co.

Morley, M.F. 1978(b). The value added statement - a British innovation. CA Magazine, May, 31-34.

Renshall, M., Allan, R. \& Nicholson, K. 1979. Added value in external financial reporting. London: The Institute of Chartered Accountants in England and Wales.

Rossler, G.M. \& Gourley, B.M. 1983. The value added statement. Suid-Afrikaanse Geoktrooieerde Rekenmeester, Vol. 19, No. 8: 221-225.

Roullier, J. 1978. What the value added statement should include. Accountancy, October, 99-100.

Schuitema, J. 1988. Employee reporting - a new dimension in accounting. Accountancy $S A$, November, 336-339.

Srobie, B. 1986. Reporting to employees. Accountancy SA, September, 341-344.

The Accounting Standards Steering Committee. 1975. The Corporate Report. London. 
Werth, H.C. 1985. 'n Teoretiese studie en evaluasie van die konsep toegevoegde waarde en die toegevoegde waarde-staat. Skripsie ter gedeeltelike voldoening vir die graad B. Rek.
(Hons), (s.n.).

Woolf, E. 1979. Economic reality and the value added concept. Accountancy, December, 135-137. 